Удк 616.24-002.5-008.811.9-089

DOI 10.11603/2414-4533.2017.1.7631

(๖) Ю. Ф. КОШАК, Ю. Ф. САВЕНКОВ ${ }^{1}$

Тернопільський обласний протитуберкульозний диспансер

КЗ “Дніпропетровське обласне комунальне лікувально-профрілактичне об'єднання “Фтизіатрія” ДОР

\title{
Порівняльний аналіз ефективності хірургічного лікування хворих на поеднані форми легеневого туберкульозу та недрібноклітинного раку легень у групах хворих із застосуванням стерно-медіастиналь- ного хірургічного доступу
}

\begin{abstract}
Мета роботи: представити перший в Україні порівняльний аналіз ефективного хірургічного лікування хворих на поєднані форми легеневого туберкульозу та недрібноклітинного раку легень із застосуванням стерно-медіастинального хірургічного доступу; підвищити ефективність хірургічного лікування хворих на поєднані форми легеневого туберкульозу та недрібноклітинного раку легень.

Матеріали і методи. Було проведено ретроспективний аналіз 91 випадку лікування хворих із поєднаними формами легеневого туберкульозу та раку легень у протитуберкульозних диспансерах, хірургічних відділеннях різних регіонів України.

Результати досліджень та їх обговорення. Проаналізовано морфологічні особливості поєднаних форм легеневого туберкульозу та недрібноклітинного раку легень у групах порівняння, які досліджувалися ретроспективно. Показано провідний вплив легеневого туберкульозу на операційне лікування хворих на поєднані форми туберкульозу та раку легень у групах порівняння. Встановлено збільшення трирічної виживаності у пацієнтів основної групи, що свідчить на користь активної хірургічної тактики стерно-медіастинального доступу та застосування при цьому більш радикальної білатеральної лімфодисекції.
\end{abstract}

Ключові слова: поєднані форми легеневого туберкульозу та недрібноклітинного раку легень; стерно-медіастинальний хірургічний доступ; радикальна білатеральна лімфодисекція.

Постановка проблеми і аналіз останніх досліджень та публікацій. 3 метою вирішення завдання наукового дослідження підвищити ефективність хірургічного лікування хворих на поєднані форми легеневого туберкульозу (ТБ) та недрібноклітинного раку легень (НДРЛ) нами вдосконалено передопераційний діагностичний алгоритм та застосовано стерно-медіастинальний хірургічний доступ. Проаналізовано морфологічні особливості поєднаних форм туберкульозу й раку легень та влив активного легеневого туберкульозу на результати хірургічного лікування. При вивченні впливу туберкульозу на хід виконання стандартних торакальних хірургічних втручань у хворих на НДРЛ встановлено, що облітерація плевральної порожнини, фіброзно-склеротична деформація легеневої паренхіми та кореня легені, лімфатичних вузлів створюють технічні труднощі при обробці судин кореня легені, формуванні кукси бронха, що унеможливлюють радикальне проведення лімфодисекції.

Мета роботи: підвищити ефективність хірургічного лікування хворих на поєднані форми легеневого туберкульозу та НДРЛ шляхом вдосконалення передопераційного діагностичного алгоритму та застосування стерно-медістинального хірургічного доступу.

Матеріали і методи. Було проведено ретроспективний аналіз 91 випадку лікування хворих із поєднаними формами легеневого туберкульозу та недрібноклітинного раку легень, які лікувалися у фтизіохірургічному відділенні Тернопільського обласного протитуберкульозного диспансеру та легенево-хірургічному відділенні К3 “Дніпропетровське обласне комунальне лікувально-профілактичне об’єднання “Фтизіатрія” ДОР.

Результати досліджень та їх обговорення. Усім хворим були проведені необхідні клінічні, лабораторні та інструментальні, включаючи рентгенологічні, методи обстеження. При аналізі діагностичних алгоритмів нами були виділені їх основні групи, які дозволили запідозрити та провести діагностику виникнення недрібноклітинного раку легень на фоні туберкульозного процесу.

Основну групу склали 38 (28,3 \%) пацієнтів, у яких були застосовані вдосконалені нами методики комплексної ранньої діагностики, включаючи спіральну комп'ютерну томографію з контрастуванням, відеоторакоскопію з біопсією лімфатичних вузлів, а також радикальне хірургічне лікування із застосуванням стерно-медіастинального доступу з лімфаденектомією та білатеральною лімфодисекцією. Результати лікування оцінювали ретроспективно в групах порівняння.

У групу порівняння увійшли 53 (71,7 \%) пацієнти, яким застосовували стандартні методи діагностики та радикальне хірургічне лікування із за- 
стосуванням стандартної бокової торакотомії. Результати лікування в даній групі також оцінювали ретроспективно.

Серед хворих груп, що вивчалися, переважали пацієнти у віці від 55 до 65 років: 32 ((84,2ะ1,2) \%) хворих в основній групі та $46((86,8+1,4) \%)-$ у групі порівняння. Середній вік хворих основної групи склав $(59 \pm 1,6)$ року, групи порівняння $(61,5 \pm 1,8)$ року $(\mathrm{p}<0,05)$.

В основній групі чоловіків було 34 ((89,4+2,4) \%), у групі порівняння - $47((88,6 \pm 1,6) \%)$, жінок - 4 $((10,6+2,2) \%)$ та $6((11,4+1,5) \%)$ відповідно $(p<0,05)$.

Усім хворим, яких досліджували, безпосередньо після встановлення діагнозу легеневого туберкульозу було розпочато протитуберкульозну терапію відповідно до категорії із застосуванням 4-6 препаратів першого та другого рядів. Лікування було проведено препаратами першого ряду (ізоніазид, рифампіцин, етамбутол, піразинамід, стрептоміцин) та другого ряду, при встановленні медикаментозної стійкості мікобактерій туберкульо- зу (МБТ) (протіонамід, етіонамід, фторхінолони, циклосерин, канаміцин, амікацин, капреоміцин, ПАСК, лінезолід), з урахуванням тесту медикаментозної чутливості. Лікування було розділено на дві фази: інтенсивну (60-90 доз при 1, 2, 3 категорії та 240-300 доз при 4 категорії) та підтримувальну фазу (120 доз при 1, 2, 3 категорії та 360 доз при 4 категорії). В інтенсивній фазі при 1, 2, 3 категоріях застосовували 4 препарати, а при 4 категорії не менше 5. У підтримувальній фазі кількість препаратів зменшено до 2 при 1, 2, 3 категоріях та до 4-5 при 4 категорії. При необхідності схема лікування підлягала корекції внаслідок наростання резистентності МБТ та розвитку побічних реакцій. Хворим категорії 5.1 призначали лікування препаратами першого ряду впродовж 2 тижнів до операції та 30 доз - після операції.

У більшості $((89,6+2,9)$ \% в основній групі та $(91 \pm 3,2)$ \% в групі порівняння) пацієнти задовільно переносили призначену терапію. Розподіл хворих за категоріями представлено в таблиці 1.

Таблиця 1. Розподіл за клінічними категоріями лікування туберкульозу хворих основної групи та групи порівняння $(\mathrm{M} \pm \mathrm{m}) \%$

\begin{tabular}{|c|c|c|c|c|}
\hline \multirow{2}{*}{ Клінічні категорії } & \multicolumn{2}{|c|}{ "Основна група $(\mathrm{n}=38)$} & \multicolumn{2}{|c|}{ Герупа порівняння (n=53) } \\
\hline & $(\mathrm{M}+\mathrm{m})$ & $(\mathrm{M} \pm \mathrm{m}) \%$ & $(\mathrm{M}+\mathrm{m})$ & $(\mathrm{M}+\mathrm{m}) \%$ \\
\hline $\begin{array}{l}\text { Перша (ВДТБ при наявності деструкції та/або } \\
\text { бактеріовиділення) }\end{array}$ & $11,0+1,0$ & $28,9 \pm 1,4 *$ & $9,0 \pm 0,3$ & $17,0 \pm 2,0 *$ \\
\hline Друга (НЛТБ, ЛПП ТБ, РТБ) & $6,0 \pm 0,7$ & $15,8 \pm 2,1^{*}$ & $5,0 \pm 0,5$ & $9,4 \pm 0,8 *$ \\
\hline $\begin{array}{l}\text { Третя (ВДТБ при відсутності деструкції та } \\
\text { бактеріовиділення) }\end{array}$ & $1,0+0,5$ & $2,6 \pm 0,1 *$ & $1,0+0,8$ & $1,9 \pm 0,5 *$ \\
\hline Четверта (МРТБ, РРТБ, РифТБ) & $6,0 \pm 0,3$ & $15,8 \pm 2,7 *$ & $6,0 \pm 0,8$ & $11,3 \pm 2,4 *$ \\
\hline 5.1 (З3ТБ - залишкові зміни туберкульозу) & $21,0 \pm 1,3$ & $39,6 \pm 2,6 *$ & $21,0 \pm 1,3$ & $39,6 \pm 2,0 *$ \\
\hline
\end{tabular}

Примітка. * - рівень значимості за критерієм $\chi^{2}$ Пірсона в основній групі та групі порівняння (р>0,05).

Дуже важливим показником стану хворих вважається виділення мікобактерій туберкульозу або його відсутність, що зумовлює неможливість проведення стаціонарного лікування хворих даних груп у відділеннях онкологічного профілю за відсутності дотримання в них умов інфекційного контролю. Так, при виконанні мікробіологічного дослідження вірогідно встановлено, що в основній групі бактеріовиділення відмічали у 12
$((39,6 \pm 2,2) \%)$ хворих та у $15((28,3 \pm 1,9) \%)$ хворих групи порівняння (р>0,05).

Не менш суттєвою $€$ наявність у хворих на туберкульоз легень резистентності до мікобактерій туберкульозу, що обов'язково впливає не тільки на характер процесу, його ускладнення, але й зумовлює тривалість лікування даної категорії хворих. Детальніше профіль резистентності МБТ відображено в таблиці 2 (р>0,05).

Таблиця 2. Характеристика хіміорезистентності МБТ у хворих перед операцією (M士m) \%

\begin{tabular}{|c|c|c|c|c|}
\hline \multirow{2}{*}{ Характеристика хіміорезистентності МБТ } & \multicolumn{2}{|c|}{ Основна група $(\mathrm{n}=38)$} & \multicolumn{2}{|c|}{ Група порівняння $(\mathrm{n}=53)$} \\
\hline & абс. & $(\mathrm{M}+\mathrm{m}) \%$ & абс. & $(\mathrm{M}+\mathrm{m}) \%$ \\
\hline Відсутність резистентності & 1 & $2,6 \pm 0,7 *$ & 3 & $5,5 \pm 0,2 *$ \\
\hline Монорезистентність & 1 & $2,6 \pm 0,4^{*}$ & 2 & $3,8 \pm 0,8 *$ \\
\hline Поліхіміорезистентність & 3 & $7,9 \pm 0,5 *$ & 1 & $1,9 \pm 0,4 *$ \\
\hline Резистентність до рифампіцину (РифТБ) & 2 & $5,2 \pm 0,4 *$ & 1 & $1,9 \pm 0,8 * *$ \\
\hline Мультирезистентність та поширена резистентність & 5 & $13,1 \pm 2,1^{*}$ & 8 & $15,1 \pm 2,8$ \\
\hline
\end{tabular}

Примітка. * p - рівень значимості за критерієм $\chi^{2}$ Пірсона в основній групі та групі порівняння (р>0,05). 
Серед форм туберкульозного процесу в оперованій легені переважали зміни у вигляді конгломератів вогнищ - у $15((39,5 \pm 2,2) \%)$ в основній групі та в $23((43,4 \pm 1,8) \%)$ - у групі порівняння, а також залишкові зміни туберкульозу у вигляді фіброзу, щільних вогнищ, туберкульом з ознаками ущільнення та петрифікації, циротичних змін та санованих каверн - $8((21,0 \pm 2,5) \%)$ та $10((18,8 \pm 1,6) \%$, $\mathrm{p}<0,05)$ (табл. 3).

В усіх хворих, які увійшли в дослідження, туберкульоз легень був поєднаний із раком легень, який виник на фоні туберкульозних та посттуберкульозних морфологічних змін.

Анатомічні форми раку легені в обох групах спостереження були представлені: як периферичним (26 пацієнтів $((68,4 \pm 1,3) \%)$ в основній групі, $34((64,1 \pm 1,1) \%)$ у групі порівняння); так і центральним раком (12 $((31,5 \pm 2,1) \%)$ та 19 $((35,8 \pm 1,6) \%)$ пацієнтів відповідно, $\mathrm{p}<0,05)$, що відображено на рисунку 1.

Розподіл НДРЛ за стадіями проводили відповідно до Міжнародної класифікації TNM на основі інтраопераційної ревізії та патоморфологічного дослідження препаратів. В обох групах спостереження переважали хворі на II стадію пухлинного процесу - $28((73,7 \pm 1,7) \%)$ пацієнтів в основній та $43((81,1+2,3) \%)$ у групі порівняння $(\mathrm{p}<0,05)$. Хворі 3

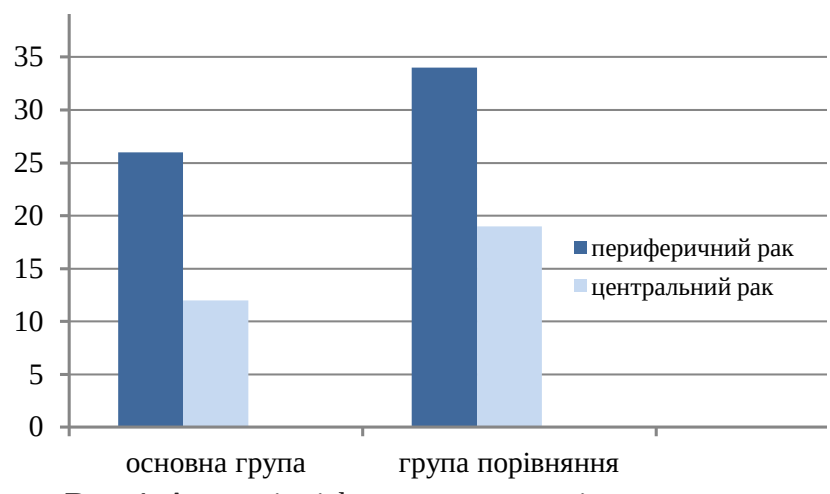

Рис. 1. Анатомічні форми раку легені у групах хворих.

III В та IV стадією дослідженню не підлягали. Розподіл раку легені за стадіями представлено в таблиці 4.

У дослідження були включені хворі на недрібноклітинний рак легень, поєднаний із туберкульозом, при цьому при виконанні патогістологічного дослідження вірогідно переважали аденокарциноми, що відображає таблиця 5.

В обох групах відмічено знижені середні показники ЖЕЛ, ОФВ, ХВЛ. Показники бронхіальної прохідності (ФЖЄЛ, Тіфно, ОФВ кож були помірно знижені, що теж вказувало на порушення ФЗД за змішаним типом. Таким чином, за показниками функції легень хворі обох груп дослідження були репрезентативними.

Таблиця 3. Форми туберкульозу легень у групах хворих (M+m) \%

\begin{tabular}{||l|c|c|c|c||}
\hline \multirow{2}{*}{ Клінічні форми туберкульозу } & \multicolumn{2}{|c|}{ Основна група $(\mathrm{n}=38)$} & \multicolumn{2}{|c||}{ Група порівняння $(\mathrm{n}=53)$} \\
\cline { 2 - 5 } & абс. & $(\mathrm{M} \pm \mathrm{m}) \%$ & абс. & $(\mathrm{M} \pm \mathrm{m}) \%$ \\
\hline Конгломерати вогнищ & 15 & $39,5 \pm 2,2^{*}$ & 23 & $43,4 \pm 1,8^{*}$ \\
\hline Залишкові зміни туберкульозу & 10 & $26,3 \pm 2,5^{*}$ & 10 & $18,9 \pm 1,6^{*}$ \\
\hline Туберкульоми з розпадом & 8 & $21,0 \pm 0,5^{*}$ & 10 & $18,9 \pm 1,6^{*}$ \\
\hline Фіброзно-кавернозний туберкульоз & 3 & $7,9 \pm 0,2 \% *$ & 5 & $9,4 \pm 0,8^{*}$ \\
\hline Циротичний туберкульоз & 2 & $5,3 \pm 0,5 \% *$ & 5 & $9,4 \pm 0,8^{*}$ \\
\hline Усього & 38 & $100 \%$ & 53 & $100 \%$ \\
\hline \hline
\end{tabular}

Примітка. * - рівень значимості за критерієм $\chi^{2}$ Пірсона в основній групі та групі порівняння (р>0,05).

Таблиця 4. Стадії раку легень у групах хворих $(\mathrm{M} \pm \mathrm{m}) \%$

\begin{tabular}{|c|c|c|c|c|c|}
\hline \multirow{2}{*}{$\begin{array}{l}\text { Стадії раку } \\
\text { легень }\end{array}$} & \multicolumn{2}{|c|}{$\begin{array}{c}\text { Основна група } \\
(\mathrm{n}=38)\end{array}$} & \multicolumn{2}{|c|}{$\begin{array}{c}\text { Група порівняння } \\
(\mathrm{n}=53)\end{array}$} & \multirow{2}{*}{$\begin{array}{l}\text { Достовірність } \\
\text { відмінностей }\end{array}$} \\
\hline & абс. & $(\mathrm{M} \pm \mathrm{m}) \%$ & абс. & $(\mathrm{M} \pm \mathrm{m}) \%$ & \\
\hline I A & 3 & $7,9 \pm 0,5 *$ & 3 & $5,7 \pm 0,6 *$ & $\begin{array}{l}\chi^{2}=0,03 \\
p=0,89\end{array}$ \\
\hline I B & 5 & $13,2 \pm 2,7 *$ & 4 & $7,5 \pm 0,4^{*}$ & $\begin{array}{c}\chi^{2}=1,03 \\
p=0,19\end{array}$ \\
\hline II A & 16 & $42,1 \pm 2,2 *$ & 24 & $45,3 \pm 1,8^{*}$ & $\begin{array}{l}\chi^{2}=0,06 \\
p=0,43\end{array}$ \\
\hline II B & 12 & $31,5 \pm 2,8 *$ & 19 & $35,8 \pm 2,2^{*}$ & $\begin{array}{l}\chi^{2}=3,83 \\
p=0,21\end{array}$ \\
\hline III A & 2 & $5,3+0,8^{*}$ & 3 & $5,7 \pm 0,8^{*}$ & $\begin{array}{l}\chi^{2}=1,85 \\
p=0,47\end{array}$ \\
\hline Усього & 38 & $100 \%$ & 53 & $100 \%$ & \\
\hline
\end{tabular}

Примітка. * - рівень значимості в основній і групі порівняння за критерієм Пірсона (p<0,05). 
Таблиця 5. Гістологічні форми раку легень у групах хворих $(\mathrm{M} \pm \mathrm{m}) \%$

\begin{tabular}{|c|c|c|c|c|c|}
\hline \multirow[t]{2}{*}{ Гістологічні форми } & \multicolumn{2}{|c|}{$\begin{array}{c}\text { Основна група } \\
(\mathrm{n}=38)\end{array}$} & \multicolumn{2}{|c|}{$\begin{array}{c}\text { Група порівняння } \\
(\mathrm{n}=53)\end{array}$} & \multirow{2}{*}{$\begin{array}{l}\text { Достовірність } \\
\text { відмінностей }\end{array}$} \\
\hline & абс. & $(\mathrm{M} \pm \mathrm{m}) \%$ & абс. & $(\mathrm{M} \pm \mathrm{m}) \%$ & \\
\hline Аденокарциноми & 24 & $63,1 \pm 1,7^{*}$ & 40 & $75,5 \pm 1,1^{*}$ & $\begin{array}{l}\chi^{2}=0,34 \\
p=0,12\end{array}$ \\
\hline Плоскоклітинний рак & 12 & $31,6 \pm 2,7 *$ & 12 & $22,6 \pm 2,2^{*}$ & $\begin{array}{l}\chi^{2}=0,09 \\
p=0,13\end{array}$ \\
\hline Інші форми & 2 & $5,3 \pm 0,6 *$ & 1 & $1,9 \pm 0,9 *$ & $\begin{array}{l}\chi^{2}=0,72 \\
p=0,26\end{array}$ \\
\hline Усього & 38 & $100 \%$ & 53 & $100 \%$ & \\
\hline
\end{tabular}

Примітка. * - рівень значимості гістологічних форм раку легень в основній і групі порівняння за критерієм Пірсона $(\mathrm{p}>0,05)$.

При виконанні електрокардіографічного обстеження, що було обов'язковим, виявлено вірогідні патологічні зміни у $25((65,8+2,4) \%)$ хворих основної групи та у $34((64,1 \pm 1,7) \%)$ пацієнтів групи порівняння $(\mathrm{p}<0,05)$

Важливим фактором у хірургічному лікуванні хворих на легеневу патологію $є$ стан бронхіального дерева. У більшості пацієнтів обох груп - 31 $((81,5 \pm 2,4) \%)$ в основній та у $47((88,7 \pm 1,7) \%)$ групи порівняння мали місце вірогідні патологічні зміни бронхіального дерева, що були зумовлені насамперед специфічним запальним туберкульозним процесом $(\mathrm{p}<0,05)$. У $5((13,1 \pm 3,1) \%)$ пацієнтів основної та у $6((11,3 \pm 2,7) \%)$ пацієнтів групи порівняння мав місце стеноз бронхів різного порядку та ступеня внаслідок тубер- кульозного запального процесу $(\mathrm{p}<0,05)$. Також у $4((10,5 \pm 3,6) \%)$ хворих в основній та у 7 $((13,2 \pm 2,2) \%)$ в групі порівняння вірогідно спостерігався ендобронхіальний ріст центрального раку з частковим або повним перекриттям просвіту бронха $(\mathrm{p}<0,05)$.

Комплексне обстеження дозволило виявити супутню патологію у $16((42,1 \pm 2,5) \%)$ пацієнтів основної групи та у $23((43,4 \pm 1,9) \%)$ пацієнтів групи порівняння $(\mathrm{p}<0,05)$ і виконати заплановане хірургічне втручання, яке наведено в таблиці 6.

Нами проведено розподілення клінічних випадків на 3 категорії (табл. 7):

1. Рак на фоні посттуберкульозних змін та так званий "рак в рубці".

2. Рак у туберкульомі.

Таблиця 6. Склад виконаних операцій у хворих груп спостереження $(\mathrm{M} \pm \mathrm{m}) \%$

\begin{tabular}{||l|c|c|c|c||}
\hline \multirow{2}{*}{ Характер супутньої патології } & \multicolumn{2}{|c|}{ Основна група, $(\mathrm{n}=38)$} & \multicolumn{2}{|c||}{ Група порівняння, $(\mathrm{n}=53)$} \\
\cline { 2 - 5 } & абс. & $(\mathrm{M} \pm \mathrm{m}) \%$ & абс. & $(\mathrm{M} \pm \mathrm{m}) \%$ \\
\hline Пневмонектомія & 29 & $76,3 \pm 1,3^{*}$ & 36 & $67,9 \pm 1,3^{*}$ \\
\hline Білобектомія & 1 & $2,6 \pm 0,3^{*}$ & 2 & $3,8+0,3^{*}$ \\
\hline Лобектомія & 8 & $21,1 \pm 0,3 *$ & 15 & $28,3 \pm 3,3^{*}$ \\
\hline Усього & 38 & $100 \% *$ & 53 & $100 \% \%^{*}$ \\
\hline \hline
\end{tabular}

Примітка. * - рівень значимості за критерієм Пірсона в основній і групі порівняння (р<0,05).

Таблиця 7. Морфологія поєднаних форм туберкульозу та раку легень у хворих груп спостереження $(\mathrm{M} \pm \mathrm{m}) \%$

\begin{tabular}{||l|c|c|c|c||}
\hline \multirow{2}{*}{ Морфологічні форми } & \multicolumn{2}{|c|}{ Основна група $(\mathrm{n}=38)$} & \multicolumn{2}{|c||}{ Група порівняння (n=53) } \\
\cline { 2 - 5 } & абс. & $(\mathrm{M} \pm \mathrm{m}) \%$ & абс. & $(\mathrm{M} \pm \mathrm{m}) \%$ \\
\hline Рак в посттуберкульозних змінах: & 31 & $81,6 \pm 2,6^{*}$ & 46 & $86,7 \pm 1,8^{*}$ \\
\hline Фіброз & 4 & $10,5 \pm 2,2^{*}$ & 6 & $11,3 \pm 2,7^{*}$ \\
\hline Цироз & 3 & $7,8 \pm 0,1^{*}$ & 4 & $7,5 \pm 0,6^{*}$ \\
\hline Щільні вогнища & 6 & $15,7 \pm 1,0^{*}$ & 8 & $15,1 \pm 3,2^{*}$ \\
\hline Конгломерати вогнищ & 5 & $13,1 \pm 3,6^{*}$ & 7 & $13,2 \pm 3,2^{*}$ \\
\hline Неактивні туберкульоми & 8 & $21,0 \pm 5,2^{*}$ & 11 & $20,7 \pm 2,4^{*}$ \\
\hline Сановані каверни & 5 & $13,1 \pm 2,9^{*}$ & 10 & $18,8 \pm 3,9^{*}$ \\
\hline Рак в активній туберкульомі & 3 & $7,8 \pm 2,1^{*}$ & 4 & $7,5 \pm 2,3^{*}$ \\
\hline Рак в стінці каверни & 4 & $10,5 \pm 2,6^{*}$ & 3 & $5,67 \pm 1,8^{*}$ \\
\hline \hline
\end{tabular}

Примітка. * - рівень значимості за критерієм $\chi^{2}$ Пірсона в основній групі та групі порівняння $(\mathrm{p}>0,05)$. 
3. Рак у стінці санованої туберкульозної каверни.

Гістологічно посттуберкульозні зміни були представлені переважно склерозом із поодинокими гранульомами, в препаратах переважала груба волокниста сполучна тканина. Іноді зустрічалися вогнища кальцифікації та відкладання кристалів холестерину. Зустрічалися ділянки гіалінозу та антракотичні включення, особливо у субплевральному шарі. Важливою ознакою посттуберкульозних рубцевих змін легені є утворення поліморфних порожнин, що доволі часто об'єднуються між собою та вкриті епітелієм. Клітини епітелію $є$ залишком альвеол та бронхіол, що замкнуті в оточенні фіброзу. Крім того, виявля- ються розширені залишки альвеол з атиповою проліферацією епітелію у вигляді поліпів. На нашу думку, саме ці клітини епітелію мають основну роль в утворенні первинного пухлинного вузла.

В основі дослідження лежить порівняльний аналіз результатів розширених лобектомій та пневмонектомій у двох групах хворих, як показано в таблиці 8.

Відмічена більш низька тривалість життя в групі порівняння. Середня тривалість життя в основній групі вірогідно складала $(48,6+4,7)$ місяця, а в групі порівняння $(37,4 \pm 5,2)$ місяця $(\mathrm{p}<0,05)$, що відображено у таблиці 9.

Таблиця 8. Інтраопераційні параметри розширених резекцій легені у групах хворих (M+m) \%

\begin{tabular}{|c|c|c|c|c|}
\hline \multirow{2}{*}{ Інтраопераційні параметри } & \multicolumn{2}{|c|}{ "Основна група (n=38) } & \multicolumn{2}{|c|}{ "Г Група порівняння (n=53) } \\
\hline & $(\mathrm{M}+\mathrm{m})$ & $(\mathrm{M}+\mathrm{m}) \%$ & $(\mathrm{M}+\mathrm{m})$ & $(\mathrm{M}+\mathrm{m}) \%$ \\
\hline $\begin{array}{l}\text { Тривалість операції (хв): } \\
\text { лобектомії } \\
\text { пневмонектомії }\end{array}$ & $\begin{array}{l}105 \pm 5,1^{*} \\
170 \pm 7,6^{*}\end{array}$ & $140+12,6$ & $\begin{array}{c}100 \pm 2,4^{*} \\
135 \pm 11,2 *\end{array}$ & $125+7,6$ \\
\hline $\begin{array}{l}\text { Інтраопераційна крововтрата (мл): } \\
\text { лобектомії } \\
\text { пневмонектомії }\end{array}$ & $\begin{array}{l}357,6 \pm 21,3 * \\
728,4 \pm 41,2 *\end{array}$ & $542,5+44,8^{*}$ & $\begin{array}{c}639,8 \pm 27,3^{*} \\
1005,7 \pm 31,4^{*}\end{array}$ & $822,3 \pm 21,7 *$ \\
\hline & $\begin{array}{l}\text { Абсолютні } \\
\text { показники }\end{array}$ & & $\begin{array}{l}\text { Абсолютні } \\
\text { показники }\end{array}$ & \\
\hline $\begin{array}{l}\text { Інтраопераційні ускладнення: } \\
\text { лобектомії } \\
\text { пневмонектомії }\end{array}$ & $\begin{array}{l}5 \\
1 \\
4\end{array}$ & $\begin{array}{l}13,2 \pm 2,6 * * \\
11,1 \pm 1,2 * * \\
13,8+2,1 * *\end{array}$ & $\begin{array}{l}12 \\
3 \\
9\end{array}$ & $\begin{array}{l}22,6 \pm 4,2 * * \\
17,6 \pm 4,7 * * \\
25,0+1,2 * *\end{array}$ \\
\hline
\end{tabular}

Примітка. * - вірогідна різниця між групами за ANOVA (p<0,05); ** - рівень значимості інтраопераційних параметрів в основній і групі порівняння за критерієм Пірсона $(\mathrm{p}<0,05)$.

Таблиця 9. Віддалені результати хірургічного лікування хворих груп спостереження (M+m) \%

\begin{tabular}{|c|c|c|}
\hline "Критерії ефективності & Основна група & Група порівняння \\
\hline Місцеві рецидиви (\%) & $10,2 \pm 1,8^{*}$ & $23,4+3,7 *$ \\
\hline Середня тривалість життя (місяців) & $48,6+4,7 *$ & $37,4+5,2 *$ \\
\hline Реактивація туберкульозу (\%) & $7,3 \pm 0,2 *$ & $9,4 \pm 0,6^{*}$ \\
\hline Летальність від прогресування туберкульозного процесу (\%) & $4,1+0,7^{*}$ & $4,3 \pm 0,8 *$ \\
\hline
\end{tabular}

Примітка: * - рівень значимості в основній і групі порівняння за критерієм Пірсона (p<0,05).

Інтраопераційна крововтрата у групі хворих 3 пневмонектомією зі стерно-медіастинального доступу була вірогідно у 1,3 раза нижчою $(\mathrm{p}<0,05)$, ніж у групі порівняння. Зниження крововтрати при виконанні операції зі стерно-медіастинального доступу досягається за рахунок відключення легені, що видаляється із загального кола кровообігу без попереднього виділення легені із зрощень.

Висновки. 1. При порівняльному вивченні частоти й характеру інтраопераційних ускладнень виявилося, що в цілому в основній групі вони зустрічаються у 2,1 раза вірогідно рідше, ніж у гру- пі порівняння $(\mathrm{p}<0,05)$. Аналіз порівнюваних груп показує, що застосування стерно-медіастинального доступу з метою розширеної пневмонектомії дозволяє своєчасно запобігти інтраопераційному пошкодженню судин кореня легені й середостіння, які охоплені рубцево-злуковим процесом внаслідок туберкульозу легень.

2. Встановлено збільшення трирічної виживаності пацієнтів основної групи та зменшення відсотка місцевих рецидивів у 1,8 раза, що свідчить на користь активної хірургічної тактики стерномедіастинального доступу та застосування більш радикальної білатеральної лімфодисекції. 


\section{СПИСОК ЛІТЕРАТУРИ}

1. Бисенков Л. Н. Хирургия далеко зашедших и осложненных форм рака легкого / Л. Н. Бисенков, А. С. Барчук, Г. М. Бояркин ; под ред. Л. Н. Бисенкова. - СПб. : ДЕАН, 2006. - 431с. 2. Радионов Б. В. Стернотомия : монография / Б. В. Радионов, Ю. Ф. Савенков. - Днепропетровск : РИА “Днепр-VAL”, 2002. -168 c.

3. Радионов Б. В. Пневмонэктомия : монография / Б. В. Радионов, Ю. Ф. Савенков. - Днепропетровск : РИА “ДнепрVAL”, 2003. - 308 c.

4. Савенков Ю. Ф. Трансстернальная заключительная пневмонэктомия у больных туберкулезом при раке ранее оперированого легкого / Ю. Ф. Савенков // Укр. пульмонол. журнал. - 2002. - № 1. - С. 58-59.

5. Scar carcinoma of the lung: historical perspective / R. K. Bobba, J. S. Holly, T. Loy, M. C. Perry // Clinical Lung Cancer. 2011. - Vol. 12. - P. 148-154.

6. Bhatt M. L. B. Pulmonary tuberculosis as differential diagnosis of lung cancer / M. L. B. Bhatt // Diagnostic dilemia. -

\section{REFERENCES}

1. Bisenkov, L.N. (Ed.). (2006). Khirurgiia daleko zashedshikh $i$ oslozhnenikh form raka legkogo [Surgery of advanced and complicated lung cancer]. Sankt Piterburg: DEAN [in Russian].

2. Radionov, B.V., \& Savenkov, Y.F. (2003). Pnevmonektomiia: Monografiia [Pneumonectomy: Monograph]. Dnepropetrovsk: RIA “Dnepr-VAL” [in Russian].

3. Radionov, B.V., \& Savenkov, Y.F. (2002). Sternotomiia: Monografiia [Sternotomy: Monograph]. Dnepropetrovsk: RIA "Dnepr-VAL" [in Russian].

4. Savenkov, Yu.F. (2002). Transternalnaia zakluchitelnaia pnevmonektomiia u bolnikh tuberkulozom pri rake ranee operirovanogo legkogo [Transsternal final pneumonectomy in patients with tuberculosis when cancer of earlier operated lung]. Ukr. Pulmonol. Zhurnal - Ukrainian Pulmonological Journal, 1, 58-59 [in Russian].

5. Bobba, R.K., Holly, J.S., Loy, T., \& Perry, M.C. (2011). Scar carcinoma of the lung: historical perspective. Clinical Lung
2012. - Vol.1, No. 1. - P. 36-42.

7. Previous lung diseases and lung cancer risk: a systematic review and meta-analysis / D. R. Brenner, J. R. Mc. Laughlin, R. J. Hung // PLOS ONE. - 2011. - Vol. 6. - e17479.

8. Cicenas S. Lung cancer in patients with tuberculosis / S. Cicenas // World Journal of Surgical Oncology. - 2007. - №5. - P. 22.

9. Coexistent Lung Carcinoma and Active Pulmonary Tubeculosis in the Same Lobe / M. Sakuraba, M. Hirama, A. Hebisava [et al.] // Ann. Thoracic Cardiovasc. Surg. - 2006. Vol. 12, No. 1. - P. 53-55.

10. Dragica P. Pesut Lung Cancer and Pulmonary Tuberculosis - a comparative population-genetic study / D. P. Pesut, D. M. Marinkovic // Balkan Journal of Medical Genesis. - 2009. - Vol. 12, No. 2. - P. 45-52.

11. Tuberculosis and risk of cancer: a Danish nationwide cohort study / D. F. Simonsen, D. K. Farkas, M. Segaard [et al.] // Int. J. Tuberc. Lung Dis. - 2014. - Vol. 18(10). - P. 1211-1219.

Cancer, 12, 148-154.

6. Bhatt, M.L.B. (2012). Pulmonary tuberculosis as differential diagnosis of lung cancer. Diagnostic Dilemia, 1 (1), 36-42.

7. Brenner, D.R., Mc. Laughlin, J.R., \& Hung, R.J. (2011). Previous lung diseases and lung cancer risk: a systematic review and meta-analysis. PLOS ONE, 6, e17479.

8. Cicenas, S. (2007). Lung cancer in patients with tuberculosis. World Journal of Surgical Oncology, 5, 22.

9. Sakuraba, M., Hirama, M., \& Hebisava A. (2006). Coexistent lung carcinoma and active pulmonary tubeculosis in the same lobe. Ann. Thoracic Cardiovasc. Surg., 12 (1), 53-55.

10. Dragica, P., \& Marinkovic, D.M. (2009). Pesut lung cancer and pulmonary tuberculosis - a comparative population-genetic study. Balkan Journal of Medical Genesis, 12 (2), 45-52.

11. Simonsen, D.F., Farkas, D.K., \& Segaard M. Tuberculosis and risk of cancer: a Danish nationwide cohort study. Int. J. Tuberc. Lung Dis., 18 (10), 1211-1219.

\title{
YU. F. KOSHAK, YU. F. SAVENKOV ${ }^{1}$
}

Ternopil Regional Phthisical Hospital

Dnipropetrovsk Regional Municipal Treatment and Prophylactic Association "Phthisiatria" DOR ${ }^{1}$

\section{COMPARATIVE ANALYSIS OF EFFECTIVENESS OF SURGICAL TREATMENT OF PATIENTS WITH COMBINED FORMS OF PULMONARY TUBERCULOSIS AND NON-SMALL CELL LUNG CANCER IN GROUPS OF PATIENTS WITH THE USE OF STERNO-MEDIASTINAL SURGICAL TECHNIQUES}

\begin{abstract}
The aim of the work: to raise efficiency of the surgical treatment of patients with combined forms of pulmonary tuberculosis and nonsmall cell lung cancer; to present the comparative analysis of effective surgical treatment of patients with combined forms of pulmonary tuberculosis and lung cancer with the use of sterno-mediastinal surgical techniques was submitted for the first time in Ukraine.

Materials and Methods. The retrospective analysis was conducted in 91 patients with combined forms of pulmonary tuberculosis and lung cancer, who were treated in TB hospitals, surgical departments of different regions of Ukraine.

Results and Discussion. The analysis of the morphological features of combined forms of pulmonary tuberculosis and non-small cell lung cancer was made in comparison groups that were explored retrospectively. The leading effect of pulmonary tuberculosis on the surgical treatment of patients with combined forms of tuberculosis and lung cancer was shown in groups of comparison. The increase of 3 years survival in patients of basic groups is set, demonstrating the advantage of active surgical tactics of sterno-mediastinal access and the appliance of more radical bilateral lymph node dissection.
\end{abstract}

Key words: combined forms of lung tuberculosis and non-small celluar lung cancer; sterno-mediastinal surgical access; radical bilateral limphodissection. 
Ю. Ф. КОШАК, Ю. Ф. САВЕНКОВ ${ }^{1}$

Тернопольский областной противотуберкулёзный диспансер

КУ “Днепропетровское областное коммунальное лечебно-профилактическое объединение “Фтизиатрия” доР"

СРАВНИТЕЛЬНЫЙ АНАЛИЗ ЭФФЕКТИВНОСТИ ХИРУРГИЧЕСКОГО ЛЕЧЕНИЯ БОЛЬНЫХ

СОЧЕТАННЫМИ ФОРМАМИ ЛЁГОЧНОГО ТУБЕРКУЛЁЗА И НЕМЕЛКОКЛЕТОЧНОГО РАКА

ЛЕГКИХ В ГРУППАХ БОЛЬНЫХ С ИСПОЛЬЗОВАНИЕМ СТЕРНО-МЕДИАСТИНАЛЬНОГО ХИРУРГИЧЕСКОГО ДОСТУПА

Цель работы: впервые в Украине представить сравнительный анализ эффективного хирургического лечения больных
комбинированными формами туберкулёза и немелкоклеточным раком легких с использованием стерно-медиастинального
хирургического доступа; повысить эффективность хирургического лечения больных с комбинированными формами
туберкулёза легких и немелкоклеточного рака легких.
Материалы и методы. Был проведен ретроспективный анализ 91 случая лечения пациентов с комбинированными формами
лёгочного туберкулёза и рака легких в противотуберкулёзных диспансерах, хирургических отделениях различных регионов Украины.
Результаты исследований и их обсуждение. Проведен анализ морфологических особенностей комбинированных форм туберкулёза
легких и немелкоклеточного рака легких в группах сравнения, которые исследовались ретроспективно. Показано ведущее влияние
лёгочного туберкулеза на хирургическое лечение больных с комбинированными формами туберкулёза и рака лёгких в группах сравне-
ния. Установлено увеличение трёхлетней выживаемости у больных основной группы, что свидетельствует в пользу активной хирургиче-
ской тактики стерно-медиастинального доступа и использования при этом более радикальной билатеральной лимфодиссекции.

Ключевые слова: сочетанные формы лёгочного туберкулёза и немелкоклеточного рака легких; стерно-медиастинальный хирургический доступ; радикальная билатеральная лимфодиссекция.

Отримано 05.01.17 